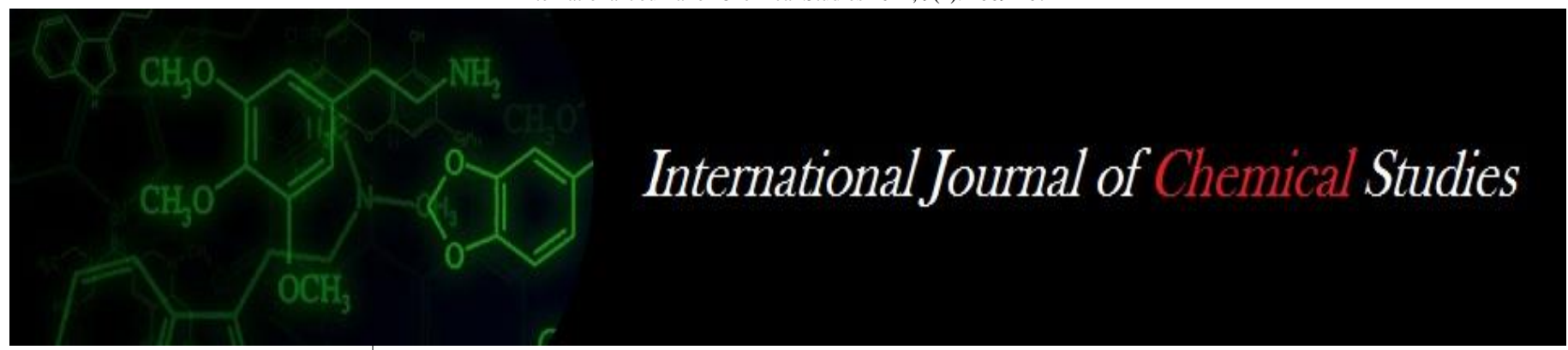

P-ISSN: 2349-8528

E-ISSN: 2321-4902

www.chemijournal.com

IJCS 2021; 9(1): 2069-2071

(C) 2021 IJCS

Received: 07-11-2020

Accepted: 23-12-2020

\section{Sadhana Kumari}

Ph.D., Scholar, Department of

Agronomy, Institute of

Agricultural Sciences, Banaras

Hindu University, Varanasi,

Uttar Pradesh, India

\section{SK Thakral}

Professor, Department of

Agronomy, College of

Agriculture, CCS Haryana

Agricultural University, Hisar,

Haryana, India

\section{Karmal Singh}

Assistant Scientist, Department

of Agronomy, College of

Agriculture, CCS Haryana

Agricultural University, Hisar,

Haryana, India

Priyanka Devi

Ph.D., Scholar, Department of

Agronomy, College of

Agriculture, CCS Haryana

Agricultural University, Hisar,

Haryana, India
Corresponding Author: Sadhana Kumari

Ph.D., Scholar, Department of Agronomy, Institute of Agricultural Sciences, Banaras Hindu University, Varanasi,

Uttar Pradesh, India

\section{Effect of nitrogen levels and Mepiquat chloride on plant height of Bt cotton (Gossypium hirsutum L.)}

\author{
Sadhana Kumari, SK Thakral, Karmal Singh and Priyanka Devi
}

DOI: $\underline{\text { https://doi.org/10.22271/chemi.2021.v9.i1ac.11528 }}$

\begin{abstract}
The field experiment was conducted at National Seed Production area of CCS Haryana Agricultural University, Hisar, during kharif 2018. The experiment comprised of three levels of nitrogen (100\%, $125 \%$ and $150 \% \mathrm{RDN}$ ) and three spray of mepiquat chloride (control, single spray at 60 DAS and two sprays at 60 and 75 DAS) was conducted in factorial randomized complete block design with three replication. Results reveal that plant height was statistically higher with $150 \% \mathrm{RDN}$, while with mepiquat chloride spray it was significantly higher in control. Highest plant height recorded at harvest with $150 \%$ RDN $(154.78,154.58$ and $144.09 \mathrm{~cm})$ followed by $125 \%$ and $100 \%$ RDN respectively. However application of mepiquat chloride reduces the plant height. Double spray of mepiquat chloride @ 20g a.i. per ha at 60 and 75 DAS significantly reduced plant height $(114.66,210.89$ and $128.4 \mathrm{~cm}$ ) compare to control, while it at par with single spray at 60 DAS respectively. The present study highlighted the practical importance of the different nitrogen levels and mepiquat chloride spray on plant height of $B t$ cotton.
\end{abstract}

Keywords: Nitrogen, mepiquat chloride, plant height, $B t$ cotton

\section{Introduction}

Cotton is one of the important cash crop in world. Cotton crop attains excessive vegetative growth mainly due to high soil fertility; coincidence of vegetative growth period with rainy season coupled with high humidity. Thick crop canopy prevents penetration of light besides shading of bolls and utilization of plant energy on the formation of vegetative stature which results in shedding of flower buds, flowers and immature bolls. Excessive vegetative growth often occurs at the expense of reproductive growth and a large fraction of squares and small bolls on the lower sympods either shed or open poorly resulting in low yield.

In India, cotton is grown on about 123 lakh hectares of land and it occupies first position in production with 377 lakh bales (each of $170 \mathrm{~kg}$ ) among all cotton producing countries in the world. Whereas, in world area under this crop is 3335 lakh hectares with 1213.7 lakh bales production. Average productivity of cotton in India is $524 \mathrm{~kg} / \mathrm{ha}$, which is low as compared to world average of $792 \mathrm{~kg} / \mathrm{ha}$ (Anonymous, 2018a) ${ }^{[1]}$. Cotton is cultivated on a large scale in Karnataka, Madhya Pradesh, Maharashtra, Gujarat, Punjab, Uttar Pradesh, Rajasthan, Haryana, and Tamilnadu. Maharashtra is the largest producer of cotton in India followed by Gujarat and Andhra Pradesh. In Haryana, area under the crop is 6.56 Lakh ha with production of $25 \mathrm{Lakh}$ bales $\left(170 \mathrm{~kg}\right.$ ) and lint yield is $648 \mathrm{~kg} / \mathrm{ha}$ in $2017-18$ (Anonymous, 2018b) ${ }^{[2]}$.

Plant growth regulators (PGRs) may enhance yield by increasing the retention of photosynthates into developing bolls. PGRs have been widely used in developed nations for increasing cotton production by adjusting plant growth and to improve lint yield and fiber quality. Gwathmey and Clement (2010) ${ }^{[4]}$ reported that source sink balance can be altered by using plant growth regulator such as mepiquat chloride (MC). Shekar et al, (2015) ${ }^{[12]}$ reported that the use of mepiquat chloride increases the $\mathrm{N}$ uptake resulting into higher seed cotton yield. Growth retardants like mepiquat chloride (MC) are known to reduce inter nodal length, thereby, reducing plant height and stimulating the translocation of photosynthesis towards reproductive sinks (developing cotton bolls), all of which result in higher yields. Mepiquat chloride (MC) is used in cotton production across the globe to control plant growth and maximize yield and quality. 
Application of MC at squaring stage or at both squaring and flowering stages significantly improved cotton quality parameters like fiber length (1.7\%) and fiber strength $(2.8 \%)$ without significant loss of yields (Ren et al, 2013) ${ }^{[11]}$. Therefore, the present study was undertaken to evaluate the effect of growth retardant (Mepiquat chloride) and varying nitrogen levels on plant height of cotton.

\section{Materials and Methods}

The study was conducted at National Seed Production Area of Choaudhary Charan Singh Haryana Agricultural University, Hisar, during kharif season of 2018. Hisar is situated in the sub-tropics at longitude $75^{\circ} 46^{\prime} \mathrm{E}$, latitude $29^{\circ} 10^{\prime} \mathrm{N}$ and altitude of $215.2 \mathrm{~m}$ above mean sea level in Haryana state of India. Hisar has semi-arid climate with very hot summer (temperature rises up to $45^{\circ} \mathrm{C}$ or more) and extremely cool winter (temperature falls up to $1-2^{\circ} \mathrm{C}$ or less than this). During summer season as well as winter season, the mean monthly temperature shows a wide range of fluctuation in minimum and maximum temperature. In December and January months, minimum temperature may fall to $0^{\circ} \mathrm{C}$. Average annual rainfall of Hisar is $450 \mathrm{~mm}$ out of the total rainfall, around $80 \%$ is received in south-west monsoon during July to September. The experiment was laid out in factorial randomized block design. First factor was different levels of nitrogen i.e. $\mathrm{N}_{1}: 100 \% \mathrm{RDN} \cdot \mathrm{N}_{2}: 125 \% \mathrm{RDN}, \mathrm{N}_{3}: 150 \% \mathrm{RDN}$ and second was mepiquat chloride $\left(\mathrm{G}_{1}\right.$ : Control, $\mathrm{G}_{2}$ : Mepiquat chloride application 20g a.i./ha at 60 DAS and G3: Mepiquat chloride application $20 \mathrm{~g}$ a.i.ha at 60 DAS and 75 DAS). All the treatments replicated three times. Recommended dose of fertilizer for $B t$ cotton was 175:60:60kg/ha applied in the field. One third quantity of nitrogen, full amount of phosphorus and potassium is supplied through urea; single superphosphate and muriate of potash, respectively at the time of sowing. Remaining $2 / 3$ quantity of nitrogen was top dressed in two equal splits; at 30 and 60 days after sowing. $\mathrm{RCH} 650$ genotype of $\mathrm{Bt}$ cotton were grown as per the recommended package of practices. The observations for plant height were recorded at 45, 75, 105, 135 days after sowing and at maturity from an area of $6 \mathrm{~m} \times 4.5 \mathrm{~m}$ in each plot. In each plot, five plants were randomly selected and tagged for the recording of different observations till maturity of the crop. All the data obtained from $B t$ cotton were statistically analyzed using the $t$-test.

\section{Result and Discussion \\ 3.1 Effect of nitrogen}

The data present in Table 1 revealed that higher doses of nitrogen increase plant height. At 45 DAS plant height (43.42, 40.62 and $40.69 \mathrm{~cm}$ respectively) was significantly higher with $150 \%$ RDN as compared to $125 \%$ and $100 \%$ RDN. The maximum plant height $(84.51,82$ and $82.2 \mathrm{~cm}$ at $75 \mathrm{DAS}$; $125.73,117.47$ and $116.82 \mathrm{~cm}$ at 105 DAS; $152.93,141.24$ and $143.16 \mathrm{~cm}$ at $135 \mathrm{DAS} ; 154.78,154.58$ and $144.09 \mathrm{~cm}$ at harvest) was recorded with the $150 \%$ RDN. This might be due to balance $\mathrm{N}$ nutrition which increases photosynthetic processes (Omran et al., 2018) ${ }^{[5]}$. The similar results recognized by Paul et al. (2016) and Rajpoot et al. (2016a, $2016 b, 2018)^{[6,7,8,9]}$.

\subsection{Effect of mepiquat chloride}

Application of mepiquat chloride were imposed from 60 DAS, hence its effect was seen from 75 DAS onwards. Table 1 revealed the mepiquat chloride significant effect on the plant height at different growth stages. At 75 DAS, significantly higher plant height $(102.82,72.35$ and $73.56 \mathrm{~cm})$ was recorded in control as compared to single and double spray of mepiquat chloride. The same trend was observed at 105,135 DAS and at harvest $(176.18,97.51$ and $86.33 \mathrm{~cm}$ at 105 DAS; 209, 126.47 and $101.87 \mathrm{~cm}$ at 135 DAS; 210.89, 128.7 and $114.16 \mathrm{~cm}$ at harvest). This may be due to the interference of this chemical as growth regulator in gibberellic acid biosynthetic pathway. Because mepiquat chloride inhibits gibberellic acid producing enzymes, causing cells to be less longitudinally and transversally developed result of which plant height decreases. The same trend of results finds by Wang et al. (2012), Reddy et al. (1992) and Brar et al. $(2000)^{[13,10,3]}$.

Table 1: Effect of different nitrogen levels and mepiquat chloride dose on plant height $(\mathrm{cm})$ of $B t$ cotton hybrid

\begin{tabular}{|c|c|c|c|c|c|}
\hline \multirow{2}{*}{ Treatments } & \multicolumn{4}{|c|}{ Days After Sowing } & \multirow{2}{*}{$\begin{array}{c}\text { At } \\
\text { Harvest }\end{array}$} \\
\hline & 45 & 75 & 105 & 135 & \\
\hline \multicolumn{6}{|c|}{ Nitrogen levels } \\
\hline $\mathrm{N}_{1}(100 \% \mathrm{RDF})$ & 40.69 & 82.2 & 116.82 & 143.16 & 144.09 \\
\hline $\mathrm{N}_{2}(125 \% \mathrm{RDF})$ & 40.62 & 82 & 117.47 & 141.24 & 154.58 \\
\hline $\mathrm{N}_{3}(150 \% \mathrm{RDF})$ & 43.42 & 84.51 & 125.73 & 152.93 & 154.78 \\
\hline S.Em \pm & 0.68 & 2.50 & 2.73 & 8.31 & 10.31 \\
\hline $\mathrm{CD}$ at $5 \%$ & 2.05 & NS & NS & NS & NS \\
\hline \multicolumn{6}{|c|}{ Mepiquat chloride dose } \\
\hline $\mathrm{G}_{1}$ (Control) & 42.2 & 102.82 & 176.18 & 209 & 210.89 \\
\hline $\mathrm{G}_{2}$ (MC@ 20g a.i./ha at 60 DAS) & 40.51 & 72.35 & 97.51 & 126.47 & 128.4 \\
\hline $\mathrm{G}_{3}(\mathrm{MC} @ 20 \mathrm{~g}$ a.i./ha at 60 and $75 \mathrm{DAS})$ & 42.02 & 73.56 & 86.33 & 101.87 & 114.16 \\
\hline S.Em \pm & 0.68 & 2.50 & 2.73 & 8.31 & 10.31 \\
\hline $\mathrm{CD}$ at $5 \%$ & NS & 7.56 & 8.27 & 25.15 & 30.64 \\
\hline
\end{tabular}




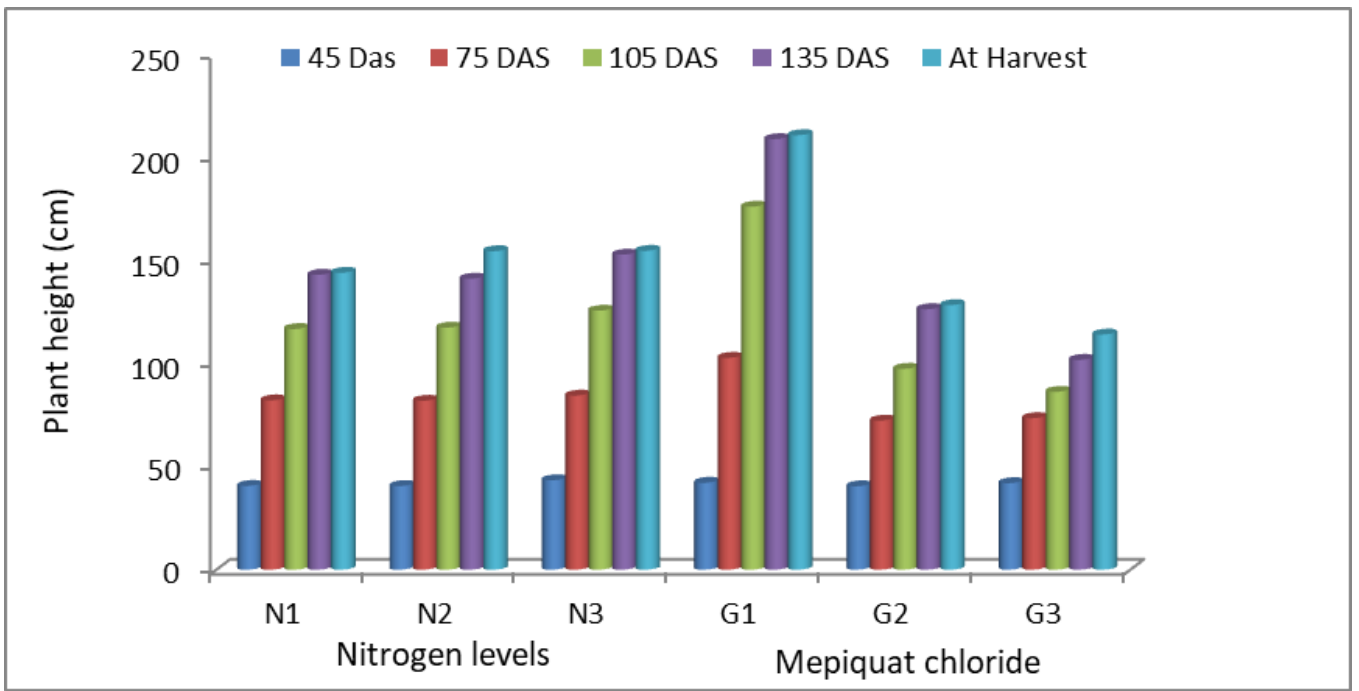

Fig 1: Effect of different nitrogen levels and mepiquat chloride dose on plant height $(\mathrm{cm})$ of $B t$ cotton hybrid

\section{References}

1. Anonymous. Accessed from https://www.usda.gov. United states department of agriculture 2018a.

2. Anonymous. The Indian express 2018 b.

3. Brar Z, Anupam S, Thakar S. Response of hybrid cotton (G. hirsutum) to nitrogen and canopy modification practices. Indian Journal of Agronomy 2000;45(2):395400.

4. Gwathmey CO, Clement JD. Alteration of cotton source sink relations with plant population density and mepiquat chloride. Field Crop Research 2010;116:101-07.

5. Omran HA, Dass A, Jahish F, Dhar S, Choudhary AK, Rajanna GA et al. Response of mungbean (Vigna radiata L.) to phosphorus and nitrogen application in Kandahar region of Afghanistan. Annals of Agricultural Research 2018;39(1):57-62.

6. Paul T, Rana DS, Choudhary AK, Das TK, Rajpoot S. Crop establishment methods and $\mathrm{Zn}$ nutrition in Btcotton: Direct effects on system productivity, economicefficiency and water-productivity in Bt-cotton-wheat cropping system and their residual effects on yield and $\mathrm{Zn}$ biofortification in wheat. Indian Journal of Agricultural Sciences 2016;86(11):1406-1412.

7. Rajpoot S, Rana DS, Choudhary AK. Effect of crop establishment methods on seed germination, seedling mortality and growth of Bt-cotton (Gossypium hirsutum) based intercropping systems. Annals of Agricultural Research 2016a;37(3):316-320.

8. Rajpoot S, Rana DS, Choudhary AK. Influence of diverse crop management practices on weed suppression, crop and water productivity and nutrient dynamics in Bt-cotton (Gossypium hirsutum) based intercropping systems in semi-arid Indo-Gangetic plains. Indian Journal of Agricultural Sciences 2016b;86(12):1637-1641.

9. Rajpoot S, Rana DS, Choudhary AK. Bt-cotton vegetable-based intercropping systems as influenced by crop establishment methods and planting geometry of Btcotton in Indo-Gangetic plains region. Current Science 2018;115(3):516-522.

10. Reddy VR, Trend A, Acock B. Mepiquat chloride and irrigation versus cotton growth and development. Agronomy Journal 1992;84:930-933.

11. Ren X, Zhang L, Dua M, Evers JB, Werf W, Tiana X et al. Managing mepiquat chloride and plant density for optimal yield and quality of cotton. Field Crop Research 2013;149:1-10.
12. Shekar K, Venkataramana M, Kumari SR. Response of hybrid cotton to chloromepiquat chloride and de topping under high density planting. Journal of Cotton Research Development 2015;29:84-86.

13. Wang $\mathrm{YH}$, Zheng $\mathrm{M}$, Gao XB, Zhou ZG. Protein differential expression in the elongating cotton (Gossypium hirsutum L.) fiber under nitrogen stress. Science China Life Sciences 2012;55:984-992. 